\title{
RACE CONSCIOUSNESS, THE AUDACITY OF EQUALITY, AND TRANSCULTURAL CRITICISM IN HASAN MINHAJ'S HOMECOMING KING
}

\author{
MUQARRAM KHORAKIWALA \\ Universidad de Valencia \\ muqarram.khorakiwala@alumnos.uva.es
}

Received 9 March 2021

Accepted 22 September 2021

\section{KEYWORDS}

Critical discourse analysis; transcultural criticism; South Asian Muslim American identity; stand-up comedy; racial humor

\section{PALABRAS CLAVE}

Análisis crítico del discurso; crítica transcultural; identidad musulmana estadounidense del sur de Asia; comedia stand-up; humor racial

\begin{abstract}
This article examines the role of the diasporic stand-up comic as a transcultural critic and the comedy set as an act of transcultural criticism of contemporary American culture. I use the framework of transcultural criticism developed by Lewis ${ }^{1}$ (2002) for the purpose of cultural investigation in Hasan Minhaj's stand-up comedy Homecoming King (2017). Through the amalgamation of political aesthetics and cultural civics, Lewis' theorization of transculturalism offers an interesting approach for critical discourse analysis of racial injustice and inequality in Muslim American stand-up comedy. Minhaj uses persuasion games and language wars to highlight the dissonance in the dominant discourse about Islam. His goal is not to be a spokesperson for Muslim Americans but to provide new imaginings to the discussion of race, religion, and belonging in the context of Brown Americans in the post $9 / 11$ era both within and outside the community.
\end{abstract}

\section{RESUMEN}

\footnotetext{
${ }^{1}$ Jeff Lewis is a professor of media and cultural studies at the Royal Melbourne Institute of Technology in Australia. His major contributions to the field of cultural studies are the conceptualization of "transculturalism" and his work on the analysis of political violence and the Western world's response to Islamist militant terrorism. For a more detailed discussion, see the following publications by Lewis: Language Wars: The Role of Media and Culture in Global Terror and Political Violence (2005), Cultural Studies (2008), Crisis in the Global Mediasphere: Desire, Displeasure and Cultural Transformation (2011), and Global Media Apocalypse (2013).
} 
Este artículo examina la función del comediante diaspórico como crítico transcultural y la comedia establecida como acto de crítica transcultural de la cultura estadounidense contemporánea. Utilizo el marco de la critica transcultural desarrollado por Lewis (2002) con el propósito de la investigación cultural en la comedia de Hasan Minhaj, Homecoming King (2017). A través de la fusión de la estética politica y la cívica cultural, la teorización del transculturalismo de Lewis ofrece un enfoque interesante para el análisis crítico del discurso de la injusticia racial y la desigualdad en la comedia stand-up estadounidense musulmana. Minhaj utiliza juegos de persuasión y guerras de idiomas para resaltar la disonancia en el discurso dominante sobre el Islam. Su objetivo no es solo ser el portavoz de los musulmanes estadounidenses, sino proporcionar nuevas imaginaciones a la discusión sobre raza, religión y pertenencia en el contexto de los estadounidenses no blancos en la era posterior al 11 de septiembre, tanto dentro como fuera de la comunidad.

\section{INTRODUCTION}

Race and racism continue to be problematic in the U.S. even today despite popular belief in the prevalent political discourse that America is evolving into a colorblind society (Brown et al. 2003; Vincenty 2020; Wingfield 2015). At the same time, the strategies to engage in the study and analysis of these concepts are changing in accordance with the continuous growth of immigrant and diasporic communities (Omi and Winant 2015). Stand-up comedy as a genre for exploring intersectionality in race and ethnicity and their effect on the performance of personhood has gained prominence in the last two decades (Daube 2010). Racial humor has been a characteristic of American stand-up comedy in its early days through blackface performances in minstrel shows in the nineteenth century (Kippola 2012; Parker 2008). It continues to be a part of performing marginality and cultural critique by stand-up comedians in the twenty-first century (Gilbert 2004). While traditionally dominated by Jewish stand-up comics in the 1960s (Limon 2000), this popular cultural phenomenon has had a powerful impact on American audiences influencing and changing worldviews, transforming culture while giving birth to its modern form towards the end of the millennium (Zoglin 2008). The shows have moved from comedy clubs in Los Angeles and New York to international blockbuster productions on global streaming media platforms (M. Johnson 2020). Like their spectators, the performers are diverse and intersectional, including people from different races and ethnicities as well as the diasporic communities with a history of immigration from nontraditional countries. Stand-up has evolved from a simplistic comedy show to a genre of observational comedy that uses the Bordieuan habitus and prevailing social norms as a fulcrum to draw global 
Race Consciousness, the Audacity of Equality,

and Transcultural Criticism in Hasan Minhaj's Homecoming King

audiences (Borns 1987; Quirk 2015). In their role as cultural critics, diasporic stand-up comedians provide observations that are relatable to minorities as well as dominant groups. They make observations "from the backwaters of life, an everyday phenomenon that is rarely noticed or discussed" by mainstream society (Double 208). Building on the work of cultural analysis undertaken by researchers in the field of stand-up comedy and using Lewis' (2002) theorization of transculturalism, I propose in this article an analysis of the unique response of one diasporic stand-up comic, Hasan Minhaj, to notions of being Muslim, Brown, and American in post 9/11 U.S.

Hasan Minhaj is an American comedian, political commentator, actor, and television host with two successful shows on Netflix. Born to parents of Indian heritage in the U.S., he graduated in political science from the University of California, Davis. Unlike his parents, Minhaj is not willing to compromise his Muslim identity and actively seeks to fit in the mainstream culture by expanding the perimeter of the very forces that seek to exclude his generation. He is an embodiment of the struggles and dilemmas faced by new citizens of the Western world and has successfully used the medium of stand-up comedy and other new media platforms to represent American Muslims. In conversation with Sam Jones (2018), Minhaj describes how Homecoming King was born from an incident when he was not allowed to take a white girl to prom. His encounters with racism throughout his childhood and adult years encouraged him to envision a "New Brown America" that distills the essence of all South Asian American immigrants who feel like insiders and outsiders at the same time. The show is a new form of stand-up comedy; part storytelling and part autobiography, which incorporates structured accounts of past traumas and future hopes (Ludwig 2018). Through tales of personal memories depicting the ubiquitous American immigrant experience, the show is relatable to both mainstream audiences and other subordinate groups due to its universality.

\section{STAND-UP COMEDY, SOUTH ASIAN AMERICAN DIASPORA, AND NEW BROWN AMERICA}

Most stand-up comedy performances include semiautobiographical and fictionalized narrations from the artist's real-life experiences (Ajaye 2002). This means that "stand-up comedians (often) appear 'as themselves' [...] stand-up comedy is a form of theater; it is not life [...] stand-up is about the re-presentation of self as if it were everyday life" (Smith 77). In the shows performed by diasporic individuals this is often not the case, as seen in the comedy sets of South Asian American comedians who are blurring the boundaries 
between their lived and imagined realities (Maheshwari 2017). They tell their own stories about growing up in the U.S. from the perspective of the "other" Asian and Brown minority. In turn, they are redefining the notion of "belonging" and what it means to be American for the secondgeneration diaspora. Unlike postcolonial migrants or those who entered the U.S. as indentured labor, the present members of South Asian diaspora have arrived in the U.S. predominantly as highly skilled migrants after the immigration reforms introduced in the late 1960s. Initially attracted to the U.S. for opportunities in the fields of higher education and scientific research, these diasporic individuals have eventually ended up living in metropolitan centers and working in global multinational organizations (Mishra 2016). For example, the CEOs of leading global American companies like Sundar Pichai of Google, Satya Nadella of Microsoft, Arvind Krishna of IBM, Shantanu Narayen of Adobe, among others, trace their origins to India. Further, Indians from the subcontinent are the fastest growing demographic in the U.S., almost doubling in number from 2.2 million in 2000 to 4.9 million in 2015. The median annual household income of the Indian diaspora is almost double the median for all U.S. households (Bhattacharjee 2018). However, they are also different from their Far East Asian counterparts, not brown in the same way as their Mexican peers, and in the case of the Muslim diaspora, although they share their religion with their Middle Eastern compeers, they are not Arabs.

Shortly after becoming a naturalized U.S. citizen in 1988, the renowned American-Canadian diasporic writer Bharati Mukherjee posed some pertinent rhetorical questions.

All around me I see the face of America changing. So do you, if you live in cities, teach in universities, ride public transport. But where, in fiction, do you read of it? Who, in other words, speaks for us, the new Americans from nontraditional immigrant countries? Which is another way of saying, in this altered America, who speaks for you?

These sentiments are beginning to change, albeit very slowly, in the literary and cultural landscape of the U.S. Apu from The Simpsons is no longer the sole voice that represents the Indian diaspora on mainstream U.S. television shows. In Hari Kondabolu's documentary film The Problem with Apu (2017), we see new vocabularies of self-expression and resistance. Kondabolu asserts that "[w]e're a generation that grew up with that character, and now we're old enough to say something about it. Now we have the power" (Rao). Today, there is a proliferation of new media platforms for disseminating South Asian cultural narratives including stand-up comedy performances. Muslim American-born comedians and actors of Indian descent like Asif Mandvi, Aman Ali, 
Race Consciousness, the Audacity of Equality,

and Transcultural Criticism in Hasan Minhaj's Homecoming King

Azhar Usman, Aziz Ansari, and Hasan Minhaj have produced and hosted award-winning stand-up comedy shows in mainstream American media. However, a recent study has revealed that $90.5 \%$ of the English language films produced globally does not include a Muslim character. There is also widespread misrepresentation in films of Muslims, who are often stereotyped as either perpetrators or targets of violence. More than half of the films analyzed in the study portrayed Muslim characters either as immigrants or located outside the country of origin where the films were produced (Khan et al. 2021). Academy award-nominated actor $\mathrm{Riz}$ Ahmed who is part of the campaign to address this misalignment argues that considering $62 \%$ of the American population has not encountered a Muslim person in their daily lives, "[t]he representation of Muslims on screen feeds the policies that get enacted, the people that get killed, the countries that get invaded." Ahmed further contests, "[t]his study shows us the scale of the problem in film, and its cost is measured in lost potential and lost lives." In the field of Muslim standup comedy in the U.S. there is an increased consciousness about race and religion in the comedy-sets of the second-generation diaspora.

Although Muslims were participating in public humor prior to the terrorist attacks in 2001, the negative social consequences of that event led to a very public response in the form of stand-up comedy. In the United States, Muslim stand-up comedy seeks to challenge negative social discrimination that judges all Muslims to be threats to public safety, and that concludes that Islam is not an American religion. (Michael, "Contemporary Muslim Comedy").

Therefore, the observations made in these performances compel us to acknowledge the parallel lives across multiple cultural and belief systems of their protagonists and their unwillingness to compromise the coexistence of these pluralities (Kay 2018). Fully aware of the inequalities imposed by the dominant group, these diasporic stand-up comics exhibit an interplay of complex identities steeped in ambivalence and hybridity (Bhabha 1990). These identities are surfaced according to the contextual and communication needs demanded by the specific cultural encounter. Their shows not only feature the nostalgic tales of displacement through stories of their first-generation parents but also deal with contemporary issues of identity politics, religion, and economic inequalities and representation in the U.S.

There is an increased consciousness of brownness amongst the South Asian American diaspora in the twenty-first century which is in alignment with the demographic changes in the U.S. Whether the U.S. is becoming more accepting of its "brown" citizens or whether the "brown" diaspora will eventually align with the mainstream "white" notions of 
American identity, mirroring the experience of earlier European settlers is yet to be seen. The category of "South Asian" itself is relatively new in the U.S. in comparison to other panethnic identifiers like "Asian American" and "Latinx". Many "desis" from India, Pakistan, and Bangladesh find this category useful since it captures their "racial positioning as brown Asians with shared cultural backgrounds, who were racialized and faced discrimination" and could not easily become a part of the mainstream (Mishra 79). However, the term "desi" as an ethnic marker or the denomination of "South Asian" as a racial categorization in the highly racialized context such as the U.S. does not have the same traction as "brown". Brownness is not used to create solidarity with other members of the subcontinental diaspora; rather, it is employed as a construct to gain visibility and raise a voice about the absurdities of American racism. This new generation of stand-up comics vocally and unreservedly use their racial positioning as "Brown Americans" to poetically and morally question the cultural, political, and financial hegemony of modern America. They reject the melting pot and salad bowl approaches to social integration and far from blending in they want to carve their own unique niches in the U.S. "South Asians in America face racism. Unlike Whiteness, the relative 'value' of a Brown identity, which has never overcome the stigma of 'foreigner,' has gone down in stock following 2001" (Sharma 21). Despite these racial, religious, and communal exclusions, Muslim American comedians of Indian origin provide a role model and help to situate the brown diaspora in the American ethnoracial and political landscape by negotiating "in-betweenness" and crafting political solidarities (Mishra 2016). They represent the aspirations of the second-generation who want to change the idea of what it means to be American and to embrace the true meaning of the equality granted to all its citizens by the U.S. constitution. They reject the submissiveness of their parents and take matters into their own hands to carve their own American dream. The members of this brown diaspora are therefore claiming their space and creating their own racial identities in the U.S. They are opting for new alternatives by rejecting the White assimilationist approaches to cultural belonging, and at the same time, are also adopting non-insular ethnic identities (Sharma 2010).

\section{CULTURAL INVESTIGATION AND ANALYSIS IN STAND-UP COMEDY THROUGH TRANSCULTURAL CRITICISM}

Several theoretical approaches have been used to analyze standup comedy performances in recent years. Limon has used Kristeva's conceptualization of abjection in the sense that "what is stood up in 
Race Consciousness, the Audacity of Equality,

and Transcultural Criticism in Hasan Minhaj's Homecoming King

stand-up comedy is abjection" (4). Limon argues that the transformation of the genre from the domain of Jewish male comedians in the 1960s to a stage where "all of America is the pool for national stand-up comedy" (3) cannot be solely attributed to the success of multiculturalism. He contends that because the Jewish comedians "stood up precisely at the place where body was idealized and materially abstracted" (8), they paved the way for stand-up comics who were not white Christian heterosexual male performers. Vigouroux has applied Bakhtin's idea of the contribution of genre such that the sociolinguistic aspect of standup comedy helps us to gain access to the sociopolitical dynamics in contemporary times. Vigouroux argues that the stand-up comics' use of heteroglossic linguistic resources reveals a new identity "which both encompasses and transcends racial and ethnic categories" (243) and that this identity "is constructed through and received by the nonratified audience with ambivalence" (243). Thomas (2015) has used Deleuze's notion of affective-cultural assemblage to assert the genre's role as both a contributor to and constrainer of racial and heteronormative discourse. Quirk (2018) has studied the sociological aspects of class and politics in stand-up comedy. Gilbert (2004) has analyzed feminist stand-up comedy, the relationship between humor and power, and the performance of marginality by female comedians as a means to understand power relations in a broader cultural context. Antoine has offered the concept of "the edge" in stand-up comedy "as an unfixed fluctuating affective perimeter that floats at the outer limits of hegemonic discourses. The edge serves as the outer rim of what we often refer to as "the mainstream" (39). Extending the concept to diasporic stand-up comedians, it can be argued that in pushing the edge of racial and ethnic hegemonies, they "exploit incongruences in dominant discourses and challenge unequal power relationships. They also position themselves as outside the mainstream in some way. Their alignment itself is part of pushing the edge." (Antoine 40). Like other Muslim stand-up comedians, Minhaj uses his "performances to argue what American Muslims should be saying and doing in order to advance their cause for social justice" (Michael, "American Muslims Stand up and Speak Out" 129). I argue that Minhaj is a transcultural critic, and his comedy set is a transcultural criticism of present-day sociocultural and political realities in the U.S. as seen by second-generation Americans of color whom Minhaj refers to as the cultural misfits that make up a "New Brown America."

With a view to re-evaluating the role of digital media and culture in its response to 9/11, cultural studies scholar Lewis argues that a transcultural reading of this event allows for a more holistic deconstruction of the power gradients rather than an interpretation of 
the collective manufactured consent based on biased assumptions. While power structures determine meaning, they are fallible and are unable to control meaning in absolute terms in culturally complex societies such as the U.S. In transculturalism, "[t]he task of criticism and reform is thus enabled by a more complete rendering of the cultural elements which are informing operations of policy, the media, and public opinion" (Lewis 27-28). His principal argument is to reexamine the interpretation of Foucault's idea of the pervasiveness of power by "two quite divergent modes of post-hegemony, post-ideology cultural movements" (15). The first group of researchers seeks a "radical expansion of human identities and expressive subjectivities" (15) while the second group has adapted Foucault's ideas "in the area of cultural policy or "cultural civics"' (15). He further argues that if cultural studies "seeks to establish itself as the evolutionary descendant of the traditional disciplines" (15), then the Birmingham school style theorization of the field needs to be revised. Lewis seeks to re-politicize our understanding of culture and cultural studies by advocating a shift from culturalism to transculturalism, such that it is pertinent to this century and that it responds to the needs of globalization and the hyperconnected mediasphere. With its basis in the poststructural theorization of culture, Lewis stresses the importance of political critique in the fields of cultural studies and the humanities to analyze political violence as well as to expose the fault lines in identity politics debates. Lewis advocates for transculturalism founded on R. Johnson's notion (qtd. Lewis 2002) wherein cultural studies plays a central role in the analysis of all forms of linguistic production. Lewis' theorization of transculturalism encompasses political aesthetics and cultural civics, adapting and extending the canonical Gramscian and Foucauldian approaches to society. It promotes a fresh mode of cultural investigation by mobilizing a new definition of culture "through the expression and deployment of new forms of cultural politics" (24). Culture is essentially created through the process of meaning-making; therefore, it must amalgamate the textual analysis aspects of cultural studies with anthropology and structural linguistics. When these aspects are enjoined with governmentality, civics, and policy debates, we attain the ability to engage more meaningfully with postmodern and poststructural realities. According to Lewis, culture is,

an assemblage of imaginings and meanings that may be consonant, disjunctive, overlapping, contentious, continuous, or discontinuous. These assemblages may operate through a wide variety of human social groupings and social practices. In contemporary culture these experiences of imagining and meaning-making are intensified through the proliferation of mass media images and information. (23-24) 
Race Consciousness, the Audacity of Equality,

and Transcultural Criticism in Hasan Minhaj's Homecoming King

By using the above definition of culture and a new form of cultural politics, transculturalism fills the gap left behind by culturalism in only partially acknowledging "the relationships between meaning and nonmeaning, ideology and subjectivity, social reform, and social imagining" (Lewis 24).

\section{MINHAJ THE TRANSCULTURAL CRITIC AND HOMECOMING KING AS TRANSCULTURAL CRITICISM}

In the remainder of this article, I will apply key characteristics of transculturalism as defined by Lewis to analyze the deeply personal anecdotes built around the themes of inequality, racial injustice, and intergenerational acceptance in Hasan Minhaj's stand-up comedy Homecoming King. The show faithfully represents the struggles and dilemmas of brown Americans in the contemporary era. Through his narrations, Minhaj highlights the need for an inclusive environment allowing for different options, perspectives, and strategies to cohabit. Through the use of observational comedy and political satire indicative of language games (Wittgenstein 1953) in his cultural performance, Minhaj puts forward the possibility to engage in social dialogue and debate with the state, by illustrating the interconnectedness between discourse and the context of use as a combined unit of reference in the process of meaning-making. Lewis claims that the textual configuration of the U.S. "is extremely volatile, transient," (30) and the role of the transcultural critic "is to limit the damage created by nodalizing and agonistic processes and to provide new imaginings for new possibilities in the human experience" (30). Lewis' key principles expose the ambivalent nature of transculturalism, uniting the critics' multi-targeted ability to wage language wars and engagement in social dialogue at all levels of the community and the nation at large with their capacity to constantly deconstruct and reconstruct reality. This essentially makes transculturalism a viable framework for decoding the U.S.' need "to form itself as a super-text, overriding and resolving the problematic through the imposition of a nodal and extraneous symbolic order" (29). The transcultural critic should be open to multiple interpretations and acknowledge the limited durability of knowledge, thereby always evaluating the truth based on a selection of divergent claims.

Like many other minorities, Muslim Americans have contributed to cultural diversity in the U.S. "But their voices have often been marginalized, a trend that has accelerated in today's political climate, as misinformation and the normalization of hate speech have given rise to divisive rhetoric and rampant Islamophobia" (McFadyen-Ketchum). For 
the voices to be heard, not just of South Asian Muslim Americans, but of other marginalized groups as well, a process of transcultural criticism can help transform the idea of nationhood and citizenship. In several interviews, Minhaj (2016; 2017) has advocated for an environment that favors complex hybrid identities with a possibility to engage in selfreflexive and self-critical social dialogue within the diasporic community and with the state. He acknowledges that even two decades after 9/11, Muslim Americans still need to account for their ethnic differences attributed to their religion and the burden of collective guilt is even more prominent. In Homecoming King, Minhaj provides a perspective on being an immigrant that has never been told so clearly and succinctly before. The first time he became conscious of his skin color was at the age of six when a little girl told him that he was the color of poop. As he grows up in a predominantly white area, there are several incidents where his "otherness" is foregrounded just because he is brown and Muslim. However, we see that one does not have to be an immigrant to experience anxiety, fear, or the feeling of discomfort in not being able to fit in. At the same time, Minhaj also believes that it is ultimately love which is intrinsically bigger than fear and the capability of seeing people as individuals on the basis of their own merits that will help foster a sense of equality.

To be able to respond to the demands of cultural hybridity, Lewis argues that "transculturalism is as interested in dissonance, tension, and instability as it is with the stabilizing effects of social conjunction, communalism, and organization" (24). Minhaj is not afraid of dealing with the issues of growing up as a brown boy and going to an all-white school in Davis, California. He narrates the incident about how the teachers were never able to pronounce his name correctly in school making rollcall a nightmare for him. Incidentally, it was his English teacher who confused his name with Saddam Hussein. Minhaj consistently uses sarcasm and figurative language throughout the show that resonates with both insiders and outsiders (Handika 2019). This memory has had a profound impact on him, so much so that, even in his short segment on TheEllenShow, he spent most of his time educating Ellen and the North American audience on how to pronounce his name correctly. His argument is that if Americans can pronounce a difficult name like Timothée Chalamet, then they should also be able to pronounce HA-sun MIN-haj. The clip went viral and has struck a chord with the second-generation diaspora who hesitate to correct people when their name is pronounced incorrectly (Husain 2020). Through this story, Minhaj highlights the various angles of culture and the ways in which meaning is created and distributed in society by those in power. 
Race Consciousness, the Audacity of Equality,

and Transcultural Criticism in Hasan Minhaj's Homecoming King

Minhaj communicates and interprets positive and negative messages with equal ease. Throughout the show he relates carefully selected personal stories that highlight racism in different social settings, from educational to professional to personal interactions between brown immigrants and white Americans. He candidly states, "on that night, September $12^{\text {th }}$, it was the first night of so many nights where my family's loyalty to this country was under attack" (HK 00:30:19-00:30:27) and questions why Muslim Americans need to prove their patriotism every time America faces a terrorist attack. After the assault on their house, his father wanted him to let go, telling him that "[t]hese things happen, and these things will continue to happen. That's the price we pay for being here" (HK 00:28:33-00:28:41). However, Minhaj highlights the intergenerational differences, and challenges his father's version of the American dream. Minhaj recounts, "[m]y dad's from that generation where he feels like if you come to this country, you pay the American dream tax. You endure racism, and if it doesn't cost you your life, pay it. There you go, Uncle Sam" (HK 00:28:48-00:29-00). But Minhaj is able to switch between the various layers of meaningmaking in a manner that allows him to both transform and be transformed by the discourse in the media, which in other words is his ability to wage language wars. He "battles bigotry with bittersweet humor" (Czajkowski) and uses "emancipatory racial humor that exposes and resists dominant power structures" (Islam iii).

As children of immigrants, the ability to speak in multiple languages is both a positive and a negative developmental aspect. Simple terms of endearment like "bhai", the word for brother in Urdu need to be justified in the presence of an all-white audience. Minhaj describes his frustration of having to explain himself to his peers when his younger sister calls him "Hasan bhai" in front of his classmates. “'What's Hasan-bye?' I went to school with a bunch of Ryan Lochtes. Just all traps. 'Uh, I don't understand other cultures, bro" (HK 00:14:45-00:14:55). Lewis posits that "[t]hese language wars create the conditions of stability and instability as individuals and groups congregate, communicate, and seek to assert their material and semiotic interests over others" (24). As a transcultural critic, Minhaj has the ability to influence the discourse both within and outside the community. He narrates the South Asian obsession with associating the consequence of every action with the reaction of other diasporic community members. The famous Urdu adage his parents use to address every conflict is Log Kya Kahenge? or "What will people say?" In other words, Minhaj deploys language wars to manage and control the semiotic, personal, and material outcomes of all his social engagements. 
Minhaj is married to a Hindu woman, and the discrimination faced by people in an inter-caste marriage is the Indian equivalent to American racism. When his father is not sure about Minhaj's choice of life partner just because she is from a different Indian religion, Minhaj questions his father "How many times do we complain about racism in our community? Now the ball is in our court, we're going to be bigoted? Dad, I promise you, God doesn't like bigotry. God's not like, 'You're racist. Good job" (HK 00:22:34-00:22:47). Minhaj has a hard time convincing his parents and, in the end, decides that he is not going to change his life just because his parents want him to appease some aunty and uncle that he's never going to see. Lewis posits that if culture is manifested through language wars, then language has the ability to create and destroy community, relationship, power, and boundaries. Minhaj uses the medium of language to stay in control of the narrative by distinguishing the different layers of discourse without caring about winning or losing the debate. It is important for him to assert his identity as both Indian and American without having to justify or choose a side. His father's reaction to the events of 9/11 leads him to advise Minhaj to hide his identity. "So, when 9/11 happened I was in high school. My dad sits everybody down. He's like, 'Hasan, whatever you do, do not tell people you're Muslim or talk about politics" (HK 00:26:2500:26:35). Minhaj, on the other hand, sarcastically tells his audience what he actually wanted to tell his father at that time. "Alright, Dad, I'll just hide it. This just rubs off" (HK 00:26:35-00:26:40) referring to the color of his skin. In this case, for Minhaj, Stuart Hall's "struggle to signify" (qtd. Lewis 2002) is not polarized in a single direction, but rather changes depending on the context, without resulting in a feeling of pride or guilt. "Minhaj's racial and ethnic humor creatively exposes, destabilizes, and dissents against the prevailing power relationships and identity constructions that sustain racial oppression as commonsense knowledge" (Islam 2018). In terms of his own response to 9/11, because he was born in the U.S., Minhaj contends that, "I actually have the audacity of equality. I'm like, 'I'm in Honors Gov, I have it right here. Life, liberty, pursuit of happiness. All men created equal.' It says it right here, I'm equal. I'm equal. I don't deserve this" (HK 00:29:01-00:29:17) and argues with his father "But isn't it our job to push the needle forward little by little? Isn't that how all this stuff happens?" (HK 00:29:59-00:30:02).

Lewis further asserts that transculturalism holds the semiotic and material aspects of culture at the same level thereby acknowledging the interconnectedness between the productive and significative aspects of communication. The latter's roots are buried deep in the historical context which significantly influences the former. Assigning a secondary 
Race Consciousness, the Audacity of Equality,

and Transcultural Criticism in Hasan Minhaj's Homecoming King

status to linguistic production is a reductive approach for the purpose of diasporic identity. Rather, a move from cultural materialism towards semiotic materialism as defined by Echeverria's thesis where production=signification, (qtd. Saenz De Sicilia and Rojas 2018) is a more viable approach. It gives the diaspora "the capacity to form and reform the activity, the material environment and, thereby, the identity of a social group, in a manner which places the possibility of different and more amenable conditions at the center of critical social enquiry" (Saenz de Sicilia and Rojas 141) by asserting the importance of both dimensions in today's global neo-liberal society. In this regard, Lewis rightly observes that "[t]ransculturalism locates relationships of power in terms of language and history" (25). Homecoming King is an example of a cultural production that voices the tensions and conflicts between the dominant group and the diaspora in a series of dialectical images. "These are made images which bring certain relationships within any social formation or articulation of modes of production into sharper focus, or into the forefront of human consciousness, not as reflections of 'reality' but as multiple-faceted (at least two-sided) image" (Neale 214).

Minhaj foregrounds the question of racial class which is often not associated with Asian Americans in comparison to Black Americans, yet remains an essential ethnic and economic trait that separates South Asians from other Asians and Latin Americans. Throughout the show, Minhaj predominantly refers to the community as brown (mentioned twenty-seven times) and not Indian (used seven times) in an attempt to both highlight the racial in-betweenness in the White/Black continuum as well as the deep obsession of the Indian diaspora with the "Fair and Lovely" culture of aspiring for whiteness. When asked by his third-grade teacher what he would like to be, a six-year-old Minhaj wants to be white. He says, to the children of immigrants, "when you're white and you're playing the video game of life, and your avatar is white, you just get asked less questions along the way" (HK 00:31:47-00:31:55). Minhaj highlights the unconscious bias in this situation and argues that the privilege accorded to white children is evident in the choices available to them. "I want to be Batman.' 'Well, of course. Batman is white. Duh!' 'I want to be president.' 'Duh! Forty-four-and-a-half presidents are white. We've had a great track record" (HK 00:31:58-00:32:15). As he grows up, for the teenaged Minhaj, going to prom with a white girl, Bethany Reed, from Nebraska was the American Dream, a privilege of equality his parents' generation had strived for. But he is turned away by Bethany's mother because this was an important American rite of passage for them, and a brown boy would not fit in the photos. Minhaj regrets being dejected and not going to the prom because he did not want to ruin their picture-perfect celebration. And the following week, when his classmates 
asked him about his absence at the prom, Minhaj takes the blame upon himself and pretends to have stood-up Bethany, who did not come to his defense either. He wonders how "people could be bigoted even as they were smiling at you. It's hard when you see people saying they love you, but they're afraid at the same time. And I didn't know what that meant" (HK 00:44:05-00:44:18). Through the use of narrative comedy as one of the tools of transcultural criticism for highlighting racial-ethnic polarities, Minhaj attempts a normalization and recentering of the immigrant and diasporic experience (MacDonald 2018).

In the America divided between post 9/11 rhetoric and the more recent anti-Muslim policies of the Trump administration, even economic globalization must contend to the emerging role of religion in the West. On the politics of fear perpetrated by conservative media channels like Fox News, Minhaj asserts that it is impossible not to encounter the "other" in a big city like New York today. Even though the brain can be racist the body will just betray the "self." Behind the enclaves of their walled spaces, white supremacists may hate people of color, but for lunch they are happy to have halal chicken and rice. "All morning they're like, 'Mexicans, All Lives Matter, Arabs... 12:01! Shawarma time!" (HK 00:47:46-00:47:52). Minhaj contends that the negative associations popularized by mainstream media, particularly of Muslims, as plane hijackers and terrorists enforce discrimination in public places. However, he also argues that Muslim Americans are present in every sphere of U.S. society from doctors to engineers to restaurateurs and by that logic the white American faces a life-threatening situation even outside the airport. In our hyperconnected world, the capacity for discourse to be produced, the mediums of its distribution, the temporality and spatiality of its reach, the distortion of its meaning through the journey before reaching the intended audience, and the multiplicity of its interpretation know no bounds. As a transcultural critic, Minhaj is wary of the language wars used by the global media in projecting the worst in the Muslim minority as the universal reality of its majority. For Lewis, "[t]ransculturalism, however, identifies these multiple flowing processes in terms of broadly contested and uneven distributions, disjunctures, and concentrations" (25). In this sense, Minhaj is able to evaluate the prolific natuer and propinquity of every message he receives from or sends out in the global mediasphere. Unlike his father, he wants to engage in an open debate about the problem of race despite facing several instances of discrimination in his personal and professional life. He reflects on the advice he would give to his younger self along the lines of, “'don't let this experience define you. It's good people and bad people. Irrespective of creed, class, color, find those people. Because love is bigger than fear.' [...] I really believe that. I really 
Race Consciousness, the Audacity of Equality,

and Transcultural Criticism in Hasan Minhaj's Homecoming King

believe love is bigger than fear" (HK 00:46:33-00:47:00). Towards the end of the show, Minhaj reveals his version of the American dream and asserts the freedom of equality granted to all American citizens. In the New Brown America, his vision is for people to stop blaming others and take control of their destinies. "It's not asking for a co-sign. It's what every generation did before you. You claim that shit on your own terms" (HK 01:02:48-01:02:54).

Meanings are produced through social assemblages and when they achieve a significant quantum they are converted into ideological and hegemonic practices. Lewis claims that "[t]he process of fixing (meaning) transgresses the inevitable dynamic of meaning-making; signifiers are strained beneath the ossifying force of fixity, eventually splintering, fissuring, and separating in a process of dissociation" (25). Minhaj is a part of the apparatus that challenges these poles of power and seeks to incorporate new meanings into the dominant culture unreservedly and unashamedly. If he can be transformed by the mainstream, he also has the power to transform the established culture by actively engaging in language warfare. Through continuous deconstruction and reconstruction of racial inequalities Minhaj forces us to do what Lewis argues, and that is "identify nodalizations and the brutish infamies of social and cultural injustice" (26).

Minhaj goes on to view his brownness as a privilege vis-à-vis the racial discrimination faced by Black Americans. His disappointment at not being able to take a white girl to prom is nothing compared to the spine-shattering violence induced by the police on African Americans even today. For a moment, he resigns to paying the dream tax to Uncle Sam but pauses to reflect about the fact that America's racial problem is not dealt with adequately. "Why is it every time the collateral damage has to be death for us to talk about this? [...] For every Trayvon Martin or Ahmed, the clock kid, there is bigotry that happens every day" (HK 00:46:10-00:46:27). Minhaj argues that the reason for this type of bigotry that transpires daily is the fear of the "other." This time he wages language war to draw a parallel between the Black community which has been historically discriminated and continues to struggle even today and the Brown community which is treading along the same trajectory. Lewis further posits that as the dominant culture is continuously challenged, the boundaries of meaning and non-meaning are rendered porous and ultimately begin to break, resulting in the emergence of new cultures from the fault lines. "The test of transculturalism is to think outside the box of one's motherland, seeing many sides of every question without abandoning conviction, and allowing for a chameleon sense of self without losing one's cultural center" (Slimbach 211). On one hand, Minhaj lets go of the hatred he has been carrying in his heart about 
Bethany and her family and on the other hand, Bethany marries an Indian guy, Rajesh Rengatramanajananam, despite her parents' narrowmindedness. She rebukes her parents and declares, "This isn't high school. Raj is a good person and so am I. So, I'm going to be with him because it's right. I hope you make up your mind" (HK 01:02:0101:02:13). Transculturalism also challenges those who use language wars to justify racism and creates heroes from the dominant group who champion the cause of immigrants for creating a level playing field. Minhaj narrates the story about the clip from Real Time with Bill Maher, where Bill tells Ben Affleck that $85 \%$ of Muslims hate Americans and should be contained. Ben reminds Bill of the result of the same strategy used by Americans towards the Japanese. In that moment, Minhaj recounts that Ben Affleck "may not be the hero we want, but he is the hero the Muslim world needs" (HK 01:05:38-01:05:42), thereby suggesting a new structural reality. Here Minhaj closes the loop of his language war by ultimately drawing the White race into the politics of identification by building solidarity with the marginalized groups.

The manner in which meaning is constructed has a direct impact on how a society evolves. If the dominant groups continue to undermine and repress the culturally marginalized "others", given the power and counter-power of the network society, such a structure is bound to collapse (Castells 2009). Lewis reasons that within transculturalism "de Certeauian and postmodern conceptions are incorporated into a broad visceral politics, which engages fully in all representational forms, including those shaped through human relationships, the body, and identity formation" (26). As a form of transcultural criticism, Homecoming King constantly strives to deconstruct and reconstruct the causalities of racial injustice and discrimination. The show exposes the dominant discourse and subjects it to analysis and critique without the fear of being repudiated by the majority cultural group or the Muslim community. Minhaj examines the path of his own parents' journey as immigrants in the U.S. as well as their prejudices and fears that prevented them from seeing themselves as equal citizens. He argues that unlike his own generation, born, raised, and educated in America, the first-generation did not have role-models and never felt at home in the U.S. At the same time before 9/11 his parents' religion was invisible and people did not even know where they came from but now it is the only thing that people care about.

We also see that Minhaj is open to cultural differences and at the same time is wary of them. This aspect of transculturalism gives him the capacity to radically engage in social, political, and ideological debates without the idea of faithfulness or faithlessness, without the fear of loyalty or disloyalty, and without the need for obedience or 
Race Consciousness, the Audacity of Equality,

and Transcultural Criticism in Hasan Minhaj's Homecoming King

transgression. Unlike his parents' generation who are happy to pay the American dream tax, Minhaj chooses what Lewis calls a "path through the minutiae and the macrocosms of various cultural assemblages, claims, and power nodes" (26). Minhaj believes in the power of love, but at the same time disagrees with the advice given by his father to always forgive others for their discriminative acts and says that "there are some days where I can forgive that person. The past is the past. Tools, Clear History. It's done. Other days, 'No, fuck that. This is House of Cards. Crush our enemies"' (HK 00:53:53-00:54:05). Therefore, Minhaj asserts his rightful place in the U.S. as a Brown, South Asian, Indian, Muslim American striving for a cosmopolitan citizenship "that recognizes that each person of that nation-state processes multiple identities that not only link him or her to their own cultural heritage, but also to the culture of the host country, continent, neighborhood, street etc." (Cuccioletta 4). In the closing story of Homecoming King, Minhaj alludes to the gradual progress being made towards mainstreaming of Brown Americans (Michael 2018) when he describes his feelings on getting selected as a correspondent for The Daily Show.

Don't you know what this means? Don't you get it? I'm the cure for racism. I cured it. Alright, maybe I didn't cure it, but everyone has a purpose. Some people were put here to find a cure for cancer or find a vaccine for Ebola. My life is definitive proof that once you go brown, you've got to lock that shit down. (HK 01:10:47-01:11:16)

\section{CONCLUSION}

In Homecoming King, Minhaj deconstructs the discursive reality of the U.S., ascribed through its power relationships on the global political stage particularly with the Middle East as well as the complicit surrender of its media's critical function in times of crisis on the American soil (Chomsky qtd. Lewis 2002). Due to the proliferation of social media and an increased awareness among the second-generation diaspora, the transcultural criticism provided by Minhaj challenges the mainstream's attempt to fix power and meaning. "New cultures and new meanings break out within the fissures and echoes of the structures that seem to contain them" (Lewis 25). Such a culture gives the marginalized the ability to communicate with each other and to form communities based on shared solidarities. Just as society comprises diverse people, culture comprises the imaginings and meanings we attribute to known and unknown phenomena, and these meanings are represented using the tools of textual analysis, always remaining fluid with the ability of being changed by space, time, and human action. Lewis' conceptualization of transculturalism discussed here, 
acknowledges the dissonant co-existence of multiple layers of culture within contemporary society. Dissonance does not necessarily mean that everything is acceptable, it merely indicates the ability to balance one's priorities and self-expression in a given space and time by respecting the sanctity of the shared and communal nature of an interdependent global society. The emergence of new media platforms has given rise to a rapid escalation of language wars and the role of the transcultural critic is to impartially mediate discursive disputes resulting from cultural differences and communication gaps. Thus, transculturalism offers us the possibility to critically examine the ways in which these language wars are shaped and conducted in stand-up comedy performances by diasporic comics.

\section{WORKS CITED}

AHMED, Riz, et al. "Coalition Unites to Define and Address Issues of Muslim Representation in Film - Pillars Fund." Pillars Fund, 10 June 2021, pillarsfund.org/2021/06/10/coalition-unites-to-define-and-addressissues-of-muslim-representation-in-film/. Accessed 14 June 2021.

AJAYE, Franklyn. Comic Insights: The Art of Stand-up Comedy. Silman-James Press, 2002.

ANTOINE, Katja. "Pushing the Edge' of Race and Gender Hegemonies through Stand-up Comedy: Performing Slavery as Anti-Racist Critique." Etnofoor, vol. 28 , no. 1,2016 , pp. 35-54.

BHABHA, Homi K. Nation and Narration. Routledge, 1990.

BHATTACHARJEE, Yudhijit. "How South Asian Americans Are Building a New American Dream." National Geographic. September 2018, nationalgeographic.com/magazine/article/south-asian-americanstereotype-kondabolu-simpsons. Accessed 11 February 2021.

BORNS, Betsy. Comic Lives: Inside the World of American Stand-up Comedy. Simon \& Schuster Inc., 1987.

BROWN, Michael K., et al. Whitewashing Race: The Myth of a Color-Blind Society. University Of California Press, 2003.

CASTELLS, Manuel. Communication Power. Oxford UP, 2009.

CHOMSKY, Noam. September 11. Allen \& Unwin, 2001.

CUCCIOLETTA, D. "Multiculturalism or Transculturalism: Towards a Cosmopolitan Citizenship." London Journal of Canadian Studies, vol. 17, 2001/2002, pp. 1-11. 
Race Consciousness, the Audacity of Equality,

and Transcultural Criticism in Hasan Minhaj's Homecoming King

CZAJKOWSKI, Elise. "Hasan Minhaj Battles Bigotry with Bittersweet Humor." The New York Times, 28 Oct. 2015, nytimes.com/2015/11/01/arts/television/hasan-minhaj-battlesbigotry-with-bittersweet-humor.html. Accessed 11 February 2021.

DAUBE, Matthew. Laughter in Revolt: Race, Ethnicity, and Identity in the Construction of Stand-up Comedy. PhD diss., Stanford University, 2010.

DOUBLE, Oliver, editor. Getting the Joke: The Inner Workings of Stand-up Comedy. Bloomsbury, 2014.

ECHEVERRÍA, Bolivar. Definición de la cultura. Curso de filosofía y economía 1981-1982. Itaca, 2001.

GILBERT, Joanne R. Performing Marginality: Humor, Gender, and Cultural Critique. Wayne State UP, 2004.

HALL, Stuart. "Cultural Studies and its Theoretical Legacies." Stuart Hall: Critical Dialogues in Cultural Studies. Ed. David Morley and Kuan-Hsing Chen. Routledge, 1996, pp. 262-275.

HANDIKA, Desfri. An Analysis of Figurative Language Used in Stand Up Comedy Performed by Hasan Minhaj Entitled Homecoming King. Skripsi thesis, Universitas Negeri Padang, 2019.

HUSAIN, Habeeba. "There Is Much More in a Name." Islamic Horizons, May 2020, pp. 49-50.

ISLAM, Tasmeea, "Bad Comic, Good Comic: The Social Construction of Brownness in the Racial and Ethnic Humor of South Asian Comedians". MA Research Paper. 24. 2018, ir.lib.uwo.ca/sociology_masrp/24. Accessed 11 February 2021.

JOHNSON, Mandee. Super Serious: An Oral History of Los Angeles Independent Stand-up Comedy. Andrews McMeel Publishing, 2020.

JOHNSON, Richard. "Three Problematics: Elements of a Theory of Working Class Culture." Working-Class Culture: Studies in History and Theory, edited by John Clarke et al., Hutchinson, 1979, pp. 201-237.

JONES, Sam. "Hasan Minhaj's 'New Brown America' Reveals Universal Relatability." Off Camera with Sam Jones, 29 Oct. 2018, offcamera.com/issues/hasan-minhaj/listen/\#.YBRFpi213IE. Accessed 11 February 2021.

KAY, K. "Down to Brown: A Footnote on British Asian and South Asian American Comedy". In: New Indian Nuttahs. Palgrave Studies in Comedy. Palgrave Macmillan, 2018. 
KHAN, Al-Baab, et al. "Missing \& Maligned: The Reality of Muslims in Popular Global Movies." USC Annenberg, June 2021, pp. 1-37, assets.uscannenberg.org/docs/aii-muslim-rep-global-film-2021-0609.pdf. Accessed 14 June 2021.

KIPPOLA, Karl M. Acts of Manhood: The Performance of Masculinity on the American Stage, 1828-1865. Palgrave Macmillan, 2012.

LEWIS, Jeff. "From Culturalism to Transculturalism." Iowa Journal of Cultural Studies, vol. 1, no. 1, 2002, pp. 14-32.

- Crisis in the Global Mediasphere: Desire, Displeasure and Cultural Transformation. Palgrave, 2011.

—. Cultural Studies. Sage, 2008.

—. Global Media Apocalypse. Palgrave Macmillan, 2013.

- Language Wars: The Role of Media and Culture in Global Terror and Political Violence. Pluto Books, 2005.

LIMON, John. Stand-up Comedy in Theory, Or, Abjection in America. Duke UP, 2000.

LUDWIG, Rachel A. "Stand up comedy, narrative, and pain; a case study: Homecoming King." Senior Capstone Projects. 745. 2018. digitalwindow.vassar.edu/senior_capstone/745. Accessed 11 February 2021.

MACDONALD, James. "Comic trans: presenting and representing the other in stand-up comedy." Live art and Performance Studies, Uniarts Helsinki, 2018.

MAHESHWARI, Laya. "The Daring Comedians Pushing Boundaries."Www.bbc.com, $11 \quad$ Sept. 2017, www.bbc.com/culture/article/20170908-the-daring-comedianspushing-boundaries. Accessed 9 June 2021.

MCFADYEN-KETCHUM, Andrew. "Muslim Americans Take the Mic." Poets \& Writers, vol. 45, no. 1, Jan. 2017, pp. 14-18.

MICHAEL, Jaclyn. "American Muslims Stand up and Speak Out: Trajectories of Humor in Muslim American Stand-up Comedy." Cont Islam, vol. 7, 2013, pp. 129-153.

- "Contemporary Muslim Comedy." Handbook of Contemporary Islam and Muslim Lives, edited by M. Woodward and R. Lukens-Bull, Springer, 
Race Consciousness, the Audacity of Equality,

and Transcultural Criticism in Hasan Minhaj's Homecoming King

2018, doi.org/10.1007/978-3-319-73653-2_41-2. Accessed 11 June 2021.

- "Religion and Representation in the 'New Brown America' of Muslim Comedy." Ecumenica, vol. 11, no. 2, 2018, pp. 62-67.

MINHAJ, Hasan. "Hasan Minhaj: Homecoming King." Edited by Christopher Storer, Netflix Official Site, 23 May 2017, netflix.com/title/80134781.

—. "Hasan Minhaj on the American Dream Tax." ART19, 25 Oct. 2016, art19.com/shows/the-mash-up-americans/episodes/2829347c-b8d34007-b41b-0bb01cdb2ca1. Accessed 11 February 2021.

—. "Hasan Minhaj Speaks on America's Fear Of Muslims, Freedom Of Speech, Bill Maher \& More." The Breakfast Club Power 105.1 FM, 8 Jun. 2017, youtu.be/gS8W4KRSvRc. Accessed 11 February 2021.

MISHRA, Sangay K. Desis Divided: The Political Lives of South Asian Americans. Minnesota UP, 2016.

MUKHERJEE, Bharati. "Immigrant Writing: Give Us Your Maximalists!" The New York Times, 28 Aug 1988, nytimes.com/1988/08/28/books/immigrantwriting-give-us-your-maximalists.html. Accessed 11 February 2021.

NEALE, R. S. "Cultural Materialism: A Critique." Social History, vol. 9, no. 2, 1984, pp. 199-215.

OMI, Michael, and Howard Winant. Racial Formation in the United States, Routledge, 2015.

PARKER, Bethany. "Probing Question: What Are the Roots of Stand-up Comedy?" Penn State University, 12 Sept. 2008, news.psu.edu/story/141330/2008/09/12/research/probing-questionwhat-are-roots-stand-comedy. Accessed 9 June 2021.

QUIRK, Sophie. The Politics of British Stand-up Comedy: The New Alternative. Palgrave Macmillan, 2018.

- Why Stand-up Matters: How Comedians Manipulate and Influence. Bloomsbury, 2015.

RAO, Mallika. "Is It Time To Retire Apu?” Huffpost, 23 Jan. 2014, huffpost.com/entry/the-simpsons-apu-racist_n_3956603. Accessed 11 February 2021.

SAENZ DE SICILIA, Andrés, and Sandro Brito Rojas. "Production=Signification: towards a Semiotic Materialism." Language Sciences, vol. 70, 2018, pp. 131-142. 
SHARMA, Nitasha Tamar. Hip Hop Desis: South Asian Americans, Blackness, and a Global Race Consciousness. Duke UP, 2010.

SLIMBACH, Richard. "The Transcultural Journey." Frontiers: The Interdisciplinary Journal of Study Abroad, vol. XI, 2005, pp. 205-230.

SMITH, Daniel R. Comedy and Critique: Stand-up Comedy and the Professional Ethos of Laughter. Bristol UP, 2018.

THOMAS, James M. "Laugh through It: Assembling Difference in an American Stand-up Comedy Club." Ethnography, vol. 16, no. 2, 2015, pp. 166186.

VIGOUROUX, Cecile B. "Genre, Heteroglossic Performances, and New Identity: Stand-up Comedy in Modern French Society." Language in Society, vol. 44, no. 2, 2015, pp. 243-272.

VINCENTY, Samantha. "Being 'Color Blind' Doesn't Make You Not Racist-in Fact, It Can Mean the Opposite." Oprah Daily, 12 June 2020, www.oprahdaily.com/life/relationships-love/a32824297/color-blindmyth-racism/. Accessed 21 Sept. 2021.

WINGFIELD, Adia Harvey. "Color Blindness Is Counterproductive." The Atlantic, 13 Sept. 2015, www.theatlantic.com/politics/archive/2015/09/colorblindness-is-counterproductive/405037/. Accessed 21 Sept. 2021.

WITTGENSTEIN, Ludwig. Philosophical Investigations. Blackwell, 1953.

ZOGLIN, Richard. Comedy at the Edge: How Stand-up in the 1970s Changed America. Bloomsbury, 2008. 